\title{
Learning English as an International Language: EFL Learners' Perceptions of Cultural Knowledge Acquisition in the English Classroom
}

\author{
Hsuan-Yau Tony Lai ${ }^{1}$ \\ ${ }^{1}$ Department of Applied Foreign Languages, National Taipei College of Business, Taipei City, Taiwan \\ Correspondence: Hsuan-Yau Tony Lai, Department of Applied Foreign Languages, National Taipei College of \\ Business, Taipei City, 100, Taiwan. Tel: 886-2-2322-6607. E-mail: tony823@ms17.hinet.net
}

Received: September 14, 2013 Accepted: October 10, 2013 Online Published: December 31, 2013

doi:10.5539/ass.v10n1p1 URL: http://dx.doi.org/10.5539/ass.v10n1p1

\begin{abstract}
Culture is an important element in the foreign language classroom. Some scholars believe that culture is the fifth language skill along with the four traditional skills (reading, writing, listening and speaking) of English. Traditionally, learning English required learners to acquire some target language cultural knowledge (e.g. British culture and/or American culture) especially in the context of English as a foreign language. However, with the increasingly important status of English as an international language, the ownership of English has been extensively discussed. Scholars have argued that English is no longer in the custody of any particular country or community. Therefore, whether we should address target language culture in the English classroom or not has become a matter of debate. The study aims to explore EFL learners' perceptions of the ownership of English and acquiring cultural knowledge in the classroom through in-depth interviews. In total, twenty undergraduates, including both English-major and non-English-major students, from three different universities in Central Taiwan participated in the study. The results show that the majority of the participants reject the notion that English belongs to particular countries in today's world. In terms of acquiring cultural knowledge, they believe that it is necessary to have some target language cultural knowledge (e.g. British culture and/or American culture) in the English classroom. However, apart from the target language cultural knowledge, they would also like to explore various cultures worldwide, using English as a communication tool to become global citizens. Therefore, rather than debate whether to teach a specific culture or language model in the English classroom, it is perhaps more meaningful and important to develop a language learner's intercultural communicative competence. These findings provide some insightful implications for English language teaching professionals and educators in terms of teaching culture in the English classroom.
\end{abstract}

Keywords: culture, language, English as an international language, intercultural competence

\section{Introduction}

Culture has long been considered the fifth language skill along with the four skills (reading, writing, listening and speaking) of English in the fields of English language teaching (ELT) and applied linguistics. Researchers have argued that culture and language are two sides of the same coin and therefore inseparable (see, for example, Brown, 2000; Mitchell \& Myles, 2004; Liddicoat, Papademetre, Scarino \& Kohler, 2003). L2 motivation scholar Gardner (2005, p.7) even argues that integrativeness (or integrative orientation), which he defines as "an individual's openness to taking on characteristics of another cultural/linguistic group," is an important motive for L2 learners in the learning process (see also Gardner, 1985, 2000, 2005). In Taiwan, English is learnt and taught as a foreign language (an EFL context) from third grade at elementary school. Since the only teaching model in the English classroom in Taiwan is the English as a native language (ENL) model, in theory most students are required to possess a native English speaker's communicative competence. Therefore, the cultural elements in the English classroom focus on the target language culture (e.g. British culture and/or American culture). However, with the present unique status of English as the most important international language in today's world, many scholars are questioning the ownership of English and the appropriateness of following native English speakers' norms in the classroom (see, for example, Jenkins, 2003, 2011; McKay, 2002, 2003). Under these circumstances, whose culture should we as English teachers and ELT professionals address (or teach) in the English language classroom? This study aims to explore EFL learners' perceptions of the ownership of English 
and the learning of culture in Taiwan.

\section{The Taiwanese English Teaching Context}

Before moving on to discuss relevant literature, I will briefly offer an overview of English education in Taiwan.

\subsection{Grade 1-9 Curriculum (Elementary School and Junior High School)}

In Taiwan, although English is taught and studied as a foreign language and not as a main language, because of the increasing importance of English, all Taiwanese students are required to study English as a compulsory subject from the third grade of elementary school until they graduate from junior high school, since the Ministry of Education launched a new curriculum (Grade 1-9 Curriculum) in 2001 (senior high school is not compulsory in Taiwan). The Grade 1-9 Curriculum, adopted by both public and private schools, divides English studying into two stages: Stage One begins at Grade 3 and ends at Grade 6 (elementary school); Stage Two begins at Grade 7 and ends at Grade 9 (junior high school). The rationale for studying English in the curriculum is based on the notion that English is an international language. According to the Ministry of Education, because of globalisation and increasing political, economic and cultural interaction in the international community, English is used on many occasions within IT, technology, industry, business and higher education, and it has become an international communication tool. Through learning English, students are able to interact with English-speaking communities (or countries) appropriately, and further understand and respect different countries and cultures in order to become global citizens.

The aims of English teaching in the curriculum are to develop student communication skills, promote their interest and motivation, and broaden their view towards today's world in order to deal with different international affairs. To help with this, instead of adopting a teacher-centred approach, the curriculum aims to create an interactive classroom atmosphere to help student learning. It focuses on training in the four skills (listening, speaking, reading and writing) of English and developing basic communicative competence and understanding of culture and social customs. There are three main objectives in the English curriculum:

1) To develop students' English communication ability, so that they can use English in a real world setting.

2) To promote students' interest and motivation in learning English, so that they can become autonomous learners.

3) To promote students' understanding of local and other cultures, so that they can compare and respect cultural differences (General Guidelines of Grade 1-9 Curriculum of Elementary and Junior High School Education).

As we can see from those objectives, the English curriculum for elementary school and junior high school in Taiwan seems to place emphasis on promoting the notion of English as an international language and fostering the students' understanding of local and foreign cultures and international affairs in the classroom. However, interestingly, the curriculum does not really address what kind of foreign cultural knowledge (e.g. native English speakers' culture or non-native speakers' culture) the students have to acquire. Nor does the curriculum address whether the students have to achieve an English native speaker's communicative competence or not, although it does point to "developing basic communicative competence". However, to my knowledge, as I am Taiwanese and was educated in Taiwan, I perhaps could argue that when Taiwanese refer to foreign cultures in the English classroom, the first impression is likely to be a native English speaker's culture (especially American culture). English native speaker language models (especially American English) and cultural elements have substantially dominated English education in Taiwan.

\subsection{English Education at the Tertiary Level}

Different from the 1-9 Grade Curriculum discussed above, at the tertiary level, every university is given full authority by the Ministry of Education and is recognised as a self-governing individual institution. Since every university can establish their own regulations, curricula, tenets and colleges, it is difficult to analyse the English education at the tertiary level as a whole. However, I will briefly discuss this by looking at a number of universities' websites and based on my knowledge and understanding as a Taiwanese.

There are two main types of university in Taiwan-comprehensive universities and technology universities. Although some new comprehensive universities were established in recent years, most comprehensive universities were founded before the 1990s and are considered to be "old", "prestigious" and "difficult to get in," among many Taiwanese. Those universities are mainly research and theory orientated. On the other hand, the second type of university - technology universities - aims to combine practice with theory. All technology universities were founded after the 1990s because of the demand for balancing emphasis on theory and practice. Since many technology universities endeavour to attract students by emphasising their pragmatic features, 
comprehensive universities have also begun to put some practical elements into the curriculum recently. However, overall, comprehensive universities are closer to the academic end and technology universities lean towards the pragmatic end. Although the orientation of both types of university might be different, today most universities have rather similar objectives or visions, such as fostering an "innovative and cosmopolitan outlook for the new century", "globalisation", and "future-orientated education" in order to develop students' skills and ability to face the rapidly changing and competitive world.

Since the orientation of both types of university is different, focus of English education varies as well. Apart from training in the four skills (listening, speaking, reading and writing), English departments in comprehensive universities put more emphasis on literature and linguistics. The students at those English departments (comprehensive universities) may have to study a broad range of Western literature such as English and American literature, and linguistic subjects such as phonetics, syntax, semantics, psycholinguistics, socio-linguistics and pragmatics. More recently, due to the popularity of English language teaching, there has been a great demand for TESOL (Teaching English to Speakers of Other Languages) or ELT-related subjects, such as methods of teaching English or syllabus design, which have also been added to the curriculum. Most of these English departments are called "Department of Foreign Languages and Literatures", "Department of English Language, Literature and Linguistics" or "Department of English".

Unlike English departments at comprehensive universities, English departments at technology universities aim to combine English with other foreign languages and practical subjects, such as business, information science and translation, apart from consolidating their students' four skills. One English department introduces the modules they offer on their website as "freeing students from the traditional framework of language and literature learning". These English departments are practice-orientated and aim to help students to "become better adapted to the diverse needs in the job market". In general, these English departments are called the "Department of Applied Languages", "Department of Applied English" or "Department of English".

Apart from those English-major students, all non-English-major students are also obligated to take English lessons (mainly the four skills) as a compulsory subject in either their first or first and second year, depending on the university's policy. Many universities even offer some English modules, such as travelling English, news in English, entertainment English, etc., as an optional subject for students to select in their third and fourth years.

So although universities in Taiwan are self-governing individual institutions and can establish their own curricula, the current objectives (or visions) for many universities seem to focus on globalisation and developing their students' skills and ability to face the rapidly changing and competitive world, which is similar to the rationale for the Grade 1-9 Curriculum, as discussed in Section 2.1. Nevertheless, although English departments at comprehensive universities may address the issue of globalisation and/or using English in a multilingual (or multicultural) setting in their goals, the curriculum still includes some elements of target cultural knowledge. Conversely, English departments at technology universities seem to place more emphasis on pragmatic subjects and enter the "target language culture free zone".

\section{Literature Review}

In this section, relevant literature including the definition of culture, the relationship between culture and language will be discussed.

\subsection{The Definition of Culture}

What is culture? As Nemni (1992) and Street (1993) believe, this is not an easy question to answer because the world today is increasingly international. Indeed, Kroeber and Kluckhohn (1954) found over three hundred definitions of culture in their study, which discusses the issues involved in communicating and teaching culture. Scholars have offered various definitions of culture (see, for example, Brooks, 1975; Brown, 2000; Friedle, 1976; Hinkel, 1999; Kramsch, 1998; Liddicoat et al., 2003). As Liddicoat et al. (2003, p. 45) claim, culture is: a complex system of concepts, attitudes, values, beliefs, conventions, behaviours, practices, rituals and lifestyles of the people who make up a cultural group, as well as the artefacts they produce and the institutions they create.

However, the notion of culture is more complex than this. Culture has different levels and elements. For a large number of people, culture will be defined at a national level such as British, American, Taiwanese or Japanese culture. Dahl (2004) cites Hofstede (1991; see also G. Hofstede, G. J. Hofstede, \& Minkov, 2010) and Smith and Bond (1998) to make the point that there are several reasons for this. These include the fact that the nationality of a person can be established easily and that people from the same country are normally shaped by the same values and norms. However, Dahl (ibid.) also indicates that, in fact, a culture may cross political and language boundaries, for example, "Latin culture" refers to a culture which is shared by countries such as Italy, Spain and 
Brazil.

At the other extreme, the notion of sub-cultures is a distinct level of culture as well. Holliday (1999) distinguishes between different levels of culture by claiming that there are two paradigms of culture-small cultures and large cultures. Large cultures refer to specific ethnic, national and international groups, for example, Japanese culture. Under the umbrella of large cultures, there are sub-cultures contained within and subordinate to them. Small cultures refer to a group which has a cohesive behaviour but are not necessary subordinate to or contained within large cultures.

A number of scholars have discussed the various elements of culture. For instance, Saville-Troike (1975) claims that culture has both "material" manifestations, which can be seen, and "non-material" manifestations, which are difficult to observe. As well as this, Kramsch $(1993,1995)$ mentions two cultural components- "material productions," such as literature, artefacts of everyday life and "the ground of meaning" which includes attitudes, beliefs, ways of thinking. The cultural elements suggested by Cortazzi and Jin (1995) (see Figure 1) is also similar to the depiction of the Cultural Iceberg Model in Gibson (2002), as developed by French and Bell (1979) and Selfridge and Sokolik (1975) (see Figure 2).

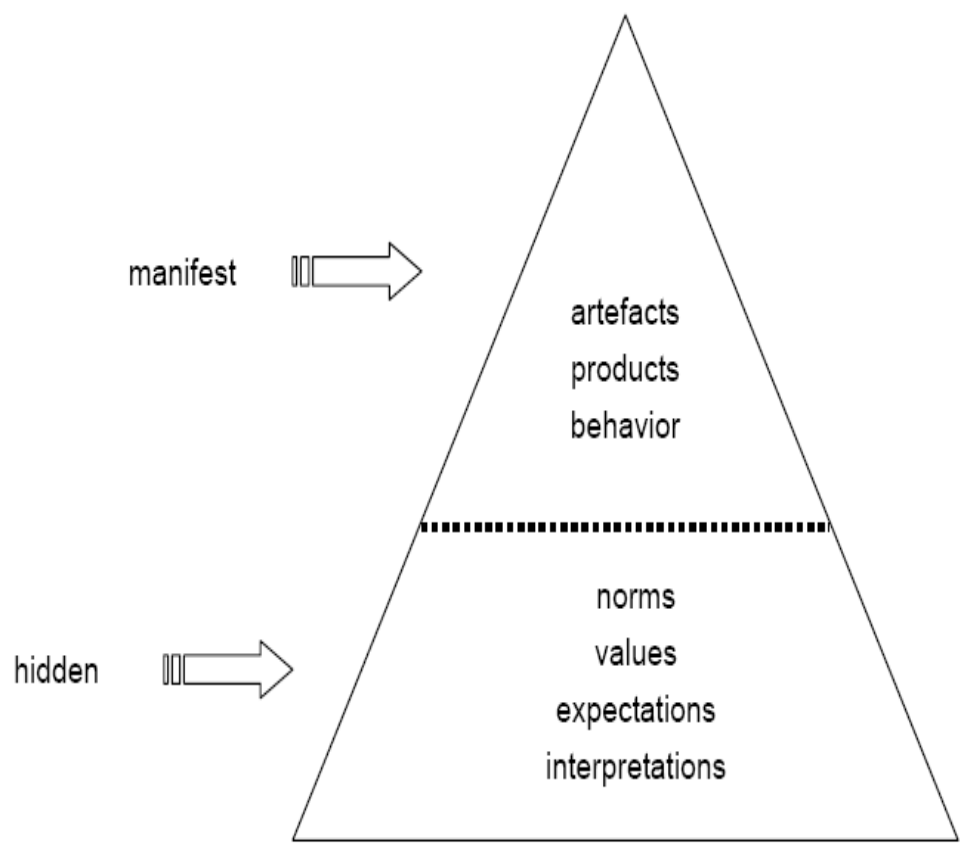

Figure 1. Manifest culture vs. Hidden culture (Cortazzi \& Jin, 1995, p. 208)

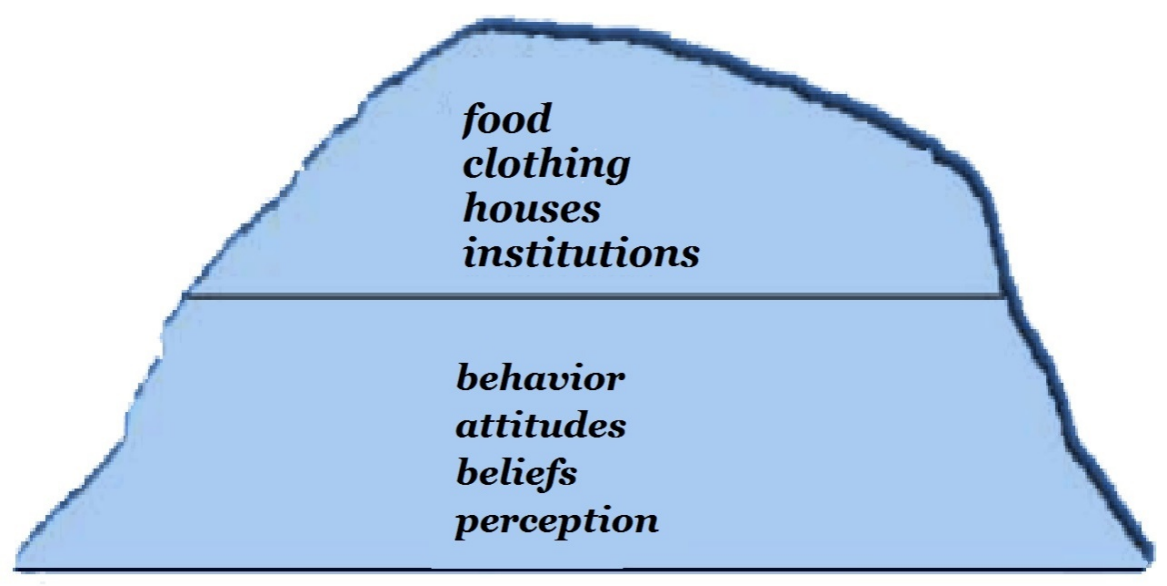

Figure 2. Cultural iceberg 
Both of these divide cultural elements into two levels - the manifested level (above the water), such as food, clothing, products and artefacts, and the hidden level (under the water), such as attitudes, beliefs and norms. Stapleton (2000) also uses the terms "overt culture" and "covert culture" to demonstrate a similar concept.

Another well-known dichotomy is between big ' $C$ ' versus little 'c' culture (Battista, 1984; Flewelling, 1993, 1994; Lee, 2009; Peterson, 2004; Stempleski, 2000). Big "C" culture includes art, music, philosophy, technology and the literature of a country or ethnic groups. Little "c" culture means the "everyday" culture, which includes what we learn at school, our social customs, what we eat and so on.

In addition to the definitions, levels and elements of culture outlined above, Robinson (1988) argues that it is important to understand culture as dynamic rather than static. His perspective on culture illustrates that culture is a product of meaning and experience and that these two elements influence each other and are constantly changing.

\subsection{Language and Culture}

Perceptions of the relationship between culture and language will be reflected in the cultural and language models employed in the foreign language classroom. The famous Sapir-Whorf Hypothesis (Kramsch, 1998) argues that a conceptual system is embodied in the language and language influences our perceptions and thought processes. This implies that language is closely tied up with culture. Alptekin (2002) points out that learning a foreign language is a kind of enculturation. Williams and Burden (1997) also claim that learning a language is like slipping into someone else's shoes. This implies that the learners not only learn a system of rules or a grammar, but also adopt new social and cultural behaviours (see also J. Bennett, M. Bennett, \& Allen, 2003; Brown, 2000; Liddicoat et al., 2003; Mitchell \& Myles, 2004). From this viewpoint, foreign languages cannot be taught separately from target culture. It suggests that students have to "act" like English native-speakers or even need to "become English-speaking people" to be successful language learners (Latulippe, 1999). The implication of this perspective for teaching materials is that target language culture materials, for example, British or American culture, need to be employed in the EFL classroom. Cortazzi and Jin (1999) suggest that another reason for promoting target language culture is that this can promote student interest in learning English because of the popularity of Western films and music. Further, the contents are relevant for those students who are preparing to visit or study in English-speaking countries. However, in recent years, with English being used increasingly as the most important international language globally, there have been considerable debates about whether this means that when we teach English, we have to teach (or address) the target language culture, e.g. British or American culture. Since much communication in English today involves non-native English speakers only, scholars are questioning the ownership of English (see, for example, Jenkins, 2003, 2011; McKay, 2002, 2003). They argue that English is no longer exclusive to any English-speaking countries or communities, but is, in fact, shared by people who speak it in order to communicate across different linguistic and cultural boundaries. The debate on the ownership of English and the reality of the varieties of English in the world have prompted scholars to question the appropriateness of following the English as a native language (ENL) model (i.e. the aspiration to possess a native English speaker's communicative competence) in the English classroom (see, Jenkins, 2003, 2011; McKay, 2002, 2003; Nelson, 1995; Kachru \& Nelson, 2006). Alptekin (2002, p. 57) even criticises the native pedagogic model based on the notion of communicative competence as being utopian, unrealistic, and constraining.

Although the notion of employing target language culture to teach a foreign language was a mainstream view in TESOL for many years, it has been criticised in recent years. At one level, this is because the target language cultural content may well be seen as irrelevant and uninteresting to some students. More significantly, however, such a cultural model is seen as problematic because it represents a "monocultural" view of culture (Murphy, 1988; see also Kachru \& Nelson, 2006).

As Risager (1998, p. 243) claims, the notion of target language culture is based on "the concept of the single culture, associated with a specific people, a specific language, and normally with a specific territory.” Thus, Rich (2003) argues that this notion is limited because it equates culture with nation, for example, English equates with British or American culture. Another problem with such a model is that it does not address learners' own culture or relations between the target countries and the learners' own culture and other countries (Risager, 1998). An additional reason to reject this is due to historical associations of some peoples' target language as a feature of colonisation. Thus, Pennycook (1989) argues, this view of the relationship between language and culture maybe will be seen as a mechanism of control and dominance of one group of people over another. The debate as to whether we should follow native English speakers' norms (and culture) in the classroom has been discussed extensively. Rather than argue whose culture we should address in the English classroom, I would like to draw 
on Byram's (1997) notion of "intercultural communicative competence" to approach this controversial issue from a different perspective. According to Ho (2009, p. 64) citing Byram, Gribkova and Starkey (2002, p.10), intercultural communicative competence refers to the "ability to ensure a shared understanding by people of different social identities, and [the] ability to interact with people as complex human beings with multiple identities and their own individuality" (see also Hall, 2002). Intercultural competence is the overall capability of an individual to cope with different challenges of intercultural communication, such as cultural difference, unfamiliarity and the tensions and conflicts that come with this process. Byram (2006, p. 22-26) further points out that an interculturally competent learner should possess the following capacities:

1) Attitudes/Affective capacities

--Acknowledgment of the identities of others

--Respect for otherness

--Tolerance for ambiguity

--Empathy

2) Behaviour

--Flexibility

--Communicative awareness

3) Cognitive capacities

--Knowledge

--Interpreting and relating

--Critical cultural awareness

Byram's notion of intercultural communicative competence provides us with a broad and critical view to approach the relationship between language and culture and how we see and think about culture in the English classroom today. Instead of discussing whose cultural elements we should address in the class, it might be more appropriate to raise EFL learners' cultural awareness of various cultures and develop their intercultural competence. Learners should begin by realising and understanding their own culture, respecting others' cultures and being culturally sensitive. In these circumstances, they are able to become successful communicators in any international setting.

\section{Methodology}

\subsection{Participants and Method}

This study aims to explore EFL learners' perceptions of the ownership of English today and acquiring cultural knowledge in the English classroom. As discussed in Section 2.2, since there are two types of university (comprehensive universities and technology universities) in Taiwan, the study also aims to compare and contrast the perceptions of English-major and non-English-major students at both types of university. In this study, semi-structured interviews were adopted to collect in-depth data to approach the issue. The interview (and research) questions were:

1) Do you think that English belongs to any particular country in the world today? If so, which country and why? If not, why?

2) Do you think that learning English requires learners to acquire any English-speaking country/culture knowledge? If so, which country/culture and why? If not, why?

In total, twenty participants from three different universities in Central Taiwan were involved in the interview process (see Table 1).

Table 1. Distribution of the interview participants $(\mathrm{N}=20)$

\begin{tabular}{ccc}
\hline & English majors & non-majors \\
\hline One Technology University & $\mathrm{N}=4$ & $\mathrm{~N}=5$ \\
Two Comprehensive Universities & $\mathrm{N}=5$ & $\mathrm{~N}=6$ \\
\hline
\end{tabular}




\subsection{Data Collection}

The data collection was carried out over a one-month period. Before beginning the interview, I asked former colleagues and friends who taught English at different universities to explain the purpose of the study to their students and invited volunteers to participate. Twenty students were willing to help. In other words, convenient sampling was adopted for the study. All 20 interviews were conducted in Mandarin Chinese (Taiwan's official language) since the participants preferred this. Each interview, which took place in a quiet classroom at the three universities, lasted around 20 minutes, and was audio recorded with the permission of each participant.

\subsection{Analysis}

The audio-recorded interview data were transcribed into Mandarin Chinese and then the content was analysed in English. First, I examined the data and divided them into two groups based on the research questions: the ownership of English and acquiring cultural knowledge in the English classroom. Then, if the participants believed English belonged to certain countries (e.g. the UK and/or US), a further category was created. The second group (acquiring cultural knowledge) was analysed using the same method. Since the interview data were transcribed into Mandarin Chinese and then analysed for content, in order to avoid any translation bias, I asked two Taiwanese colleagues with doctoral degrees in ELT and applied linguistics to check the raw data in Mandarin Chinese and the content analysis in English.

\section{Findings and Discussion}

Table 2 shows the participants' opinions on the issue of the ownership of English today. As we can see, almost all students (18 out of 20) in the study seemed to agree that English is an international language and it is for communication purpose and shared by the people who speak it. Interestingly, students' majors and university orientations (i.e. comprehensive and technology universities) did not affect the participants' thoughts over this issue.

Table 2. Participants' perceptions of the ownership of English

\begin{tabular}{ccccc}
\hline & $\begin{array}{c}\text { CU-EM } \\
(\mathrm{N}=5)\end{array}$ & $\begin{array}{c}\text { CU-NEM } \\
(\mathrm{N}=6)\end{array}$ & $\begin{array}{c}\text { TU-EM } \\
(\mathrm{N}=4)\end{array}$ & $\begin{array}{c}\text { TU-NEM } \\
(\mathrm{N}=5)\end{array}$ \\
\hline English belongs to particular countries & 0 & 1 (US) & 0 & 1 (UK or US) \\
English does not belong to particular countries & 5 & 5 & 4 & 4 \\
\hline
\end{tabular}

$\mathrm{N}=20 \quad(\mathrm{CU}=$ comprehensive university; $\mathrm{TU}=$ technology university; $\mathrm{EM}=$ English-majors; $\mathrm{NEM=non-English}$ majors)

As one English major from a comprehensive university commented:

I do not think English belongs to particular countries because English is a common communication tool today. Maybe it is not used in some regions, but it is still spoken by the majority of people. In this case, you cannot say who can speak it, who invents it, or who owns it.

Another English-major student from a technology university shared a similar opinion by stating, "I do not think English is used exclusively in particular countries. It is a communication tool today." Most non-English-major students in the study had the same opinions as the English-major students. As one non-major from a comprehensive university said, "I do not think English belongs to particular countries. If you speak English and the person to whom you are talking speaks English too, then you two can communicate. Even if you are not in the UK or US, you can still use English to communicate in Japan or Korea." However, two non-English-major students had a different perspective from the other 18 participants. One non-major from a technology university told me, "I think English belongs to the UK or US because these two countries are mainstream English-language speaking countries." Nevertheless, the majority of the interview participants were in fact aware of the notion of English as an international language and believed that English does not belong to particular countries and plays a role as a communication tool today. The findings echo the argument that the English language is no longer in the possession or custody of any particular countries or communities today, as discussed in the literature review (Section 3.2). The findings also coincide with Lai's (2011) survey of 430 Taiwanese university students' perceptions of learning English as an international language. According to his research results, the majority of his survey respondents rejected the native ownership of English. Since most of the participants in the present study believed that English is an international language shared by everyone who speaks it, what were their 
perceptions of acquiring cultural knowledge in the English classroom? Table 3 shows the participants' perceptions of acquiring cultural knowledge in the class.

Table 3. Participants' perceptions of acquiring cultural knowledge

\begin{tabular}{ccccc}
\hline & CU-EM & CU-NEM & TU-EM & TU-NEM \\
$(\mathrm{N}=5)$ & $(\mathrm{N}=6)$ & $(\mathrm{N}=4)$ & $(\mathrm{N}=5)$ \\
\hline Target language culture only & 1 & 1 & 1 & 1 \\
Target language culture and other cultures & 4 & 5 & 2 & 3 \\
\hline
\end{tabular}

$\mathrm{N}=20$ (CU=comprehensive university; $\mathrm{TU}=$ technology university; $\mathrm{EM}=$ English-majors; $\mathrm{NEM=non-English}$ majors)

Most students that I interviewed in the study agreed that it was necessary to have some knowledge regarding target language culture. As one English major from a technology university commented, "I think it is necessary to learn something about British or American culture. If you understand more about the culture, then you will probably become more interested in the language, and you will want to read more books in English." Another English major from a comprehensive university said,

I think it is necessary to understand British or American culture. Our teacher told us that if you wanted to understand a foreign language, except for its grammar, structure and vocabulary, you needed to understand the culture. You have to understand the target language culture so that you can understand the language.

However, although most students agreed that it was necessary to understand target language culture, they also told me that they would not mind using English to understand other cultures such as Thai, French, European and African cultures as well. To some extent, these results reflect how the participants thought about the ownership of English. As one non-major from a technology university said, “...... The world is a global village now. So I think it is necessary to have some knowledge about various cultures." Another English major from a comprehensive university also stated:

Apart from British and American cultures, I also want to learn about South American culture, for example, Maya culture or Inca Empire. (Interviewer: So, you do not just want to know British and American cultures?) No... No... I also want to know other cultures as well.

Interestingly, two participants (an English major and a non-major from a technology university) who claimed it was unnecessary to acquire target language culture knowledge. As the English-major student commented:

If English is an international language, why should we learn about British or American culture? If the cultural knowledge is in the course book, then it is O.K. for me to learn it. However, it should not be restricted to only the UK and US. You can have more knowledge about other festivals or activities from various cultures.

Interviewer: So, you are saying that you want to use English to understand other cultures, not only British or American culture?

Interviewee: Yes. I do not want to be British or an American.

As we can see from the above discussion, although most of the participants thought that it was necessary to understand target language culture (e.g. British culture and/or American culture) when studying English, they also agreed that it would be even better to use English to broaden their view to other cultures as well. If we refer back to the discussion in the literature review, these results show that language and culture are somehow interwoven. However, whose cultural knowledge should we address in the English classroom, as English is widely used internationally? I think there is no single answer to this question. However, one argument I would like to make here is that I believe many Taiwanese EFL learners may have come closer to becoming global citizens since most of the participants in the study believe that nowadays English does not belong to any particular countries or communities and they want to understand the target language culture as well as other various cultures in the world through the medium of English. Furthermore, I believe many of them may have even developed the notion proposed by Yashima (2000, 2002, 2009, see also Yashima, Zenuk-Nishide, \& Shimizu, 2004) of an "international posture", which refers to "a tendency to see oneself as connected to the international community, have concerns for international affairs" (Yashima, 2009, p. 146) and are ready to interact with people from various countries and cultures. 
One of the ultimate goals of learning English for them seems to become interculturally competent. Crozet and Liddicoat (2000) and Liddicoat (2002) additionally provide us with strategies to develop a learner's language and cultural acquisition. According to them, intercultural language learning involves: 1. acquisition about cultures; 2. comparing cultures; 3. exploring cultures; 4. finding one's own "third place" between cultures. During the process, firstly, learners are encouraged to explore their own culture and discover the link between their own language and culture in order to interact with people from other cultures. Secondly, comparing the similarities and differences of learners' own culture(s) and the target culture may lead them "to increased cultural knowledge, understanding and acceptance, which provides a basis for successful intercultural communication" (Ho, 2009, p. 67). Finally, through this process of self-discovery, self-reflection and comparison, language learners may become an outsider of their own culture and possess a unique stance (a third place) which allows them to examine both their own and the target culture. As Ho (2009, p. 67), citing Crozet and Liddicoat (2000), claims, "[i]t is on this unbounded and dynamic space where language learners bridge the gap between cultural differences and achieve their personal and communicative goals."

\section{Conclusion and Implications}

This study aimed to explore the perceptions of English language ownership and the acquisition of cultural knowledge in the English language classroom among Taiwanese EFL learners. Although the 20 participants involved in the study might not be representative, the results still shed some light on what EFL learners in Taiwan believe when facing the rapidly changing world. Most of the participating students were fully aware of the notion of English as an international language and would like to explore and understand not only the target language culture (i.e. British culture and/or American culture) but also various cultures in the world. Therefore, apart from consolidating English learners' linguistic competence, rather than provide specific cultural knowledge (e.g. target language culture and/or local culture) passively in the English classroom, it is important to raise student cultural awareness. Byram's (1997) notion of "intercultural communicative competence" has provided us with a good starting point. Rather than debate which or whose language and cultural models we should adopt in the English classroom, I believe it is far more important to understand learners' needs and wants first and apply the most appropriate teaching model to benefit them in terms of improving their linguistic competence and help them to develop their intercultural communicative competence.

\section{References}

Alptekin, C. (2002). Towards intercultural communicative competence in ELT. ELT Journal, 56(1), 57-64. http://dx.doi.org/10.1093/elt/56.1.57

Battista, G. (1984). Language and Culture: Strategies for Teaching Language in the Classroom. Ann Arbor, Mich: U.M.I.

Bennett, J., Bennett, M., \& Allen, W. (2003). Developing intercultural competence in the language classroom. In culture as the core: Perspectives in second language learning. USA: Information Age Publishing.

Brooks, N. (1975). The analysis of foreign and familiar cultures. In R. Lafayette (Ed.), The culture revolution in foreign language teaching. Skokie, Illinois: National Textbook Company.

Brown, H. D. (2000). Principles and language learning and teaching (4th ed.). New York: Addison Wesley Longman.

Byram, M. (1997). Teaching and assessing intercultural communicative competence. Clevedon: Multilingual Matters.

Byram, M. (2006). Language teaching for intercultural citizenship: The European situation. Paper presented at the NZALT conference, University of Auckland.

Byram, M., Gribkova, B., \& Starkey, H. (2002). Developing the intercultural dimension in language teaching: a practical introduction for teachers. Strasbourg: Council of Europe.

Cortazzi, M., \& Jin, L. (1995). Culture: Hidden Resources in the English Language Classroom. Selected papers from the Proceedings of the Fourth International Symposium on English Teaching in the Republic of China. Taipei: The Crane Publishing Co.

Cortazzi, M., \& Jin, L. (1999). Cultural mirrors: Materials and methods in the EFL classroom. In E. Hinkel (Ed.), Culture in Second Language Teaching. Cambridge: Cambridge University Press.

Crozet, C., \& Liddicoat, A. J. (2000). Teaching culture as an integrated part of language: Implications for the aims, approaches and pedagogies of language teaching. In A. J. Liddicoat, \& C. Crozet (Eds.), Teaching languages, teaching cultures (pp. 1-18). Melbourne: Applied Linguistics Association of Australia. 
Dahl, S. (2004). Intercultural Research: The Current State of Knowledge. Middlesex University Discussion Paper, 26, 1-22.

Flewelling, J. (1993). Teaching Culture in the '90s: Implementing the National Core French Study of Syllabus. The Canadian Modern Language Review, 49(2), 338-344.

Flewelling, J. L. (1994). The Teaching of Culture: Guidelines from the National Core French Study of Canada. Foreign Language Annals, 27(2), 133-142. http://dx.doi.org/10.1111/j.1944-9720.1994.tb01197.x

French, W. L., \& Bell, C. H. (1979). Organization Development. New Jersey: Prentice Hall.

Friedle, J. (1976). Cultural Anthropology. New York: Harper's College Press.

Gardner, R. C. (1985). Social Psychology and Second Language Learning: The Role of Attitudes and Motivation. London: Edward Arnold.

Gardner, R. C. (2000). Correlation, causation, motivation and second language acquisition. Canadian Psychology, 41, 1-24. http://dx.doi.org/10.1037/h0086854

Gardner, R. C. (2005). Integrative motivation and second language acquisition. Joint plenary talk at Canadian Association of Applied Linguistics/Canadian Linguistics Association, May.

Gibson, R. (2002). Intercultural Business Communication. Oxford: Oxford University Press.

Hall, J. K. (2002). Teaching and Researching Language and Culture. London: Pearson Education Limited.

Hinkel, E. (1999). Culture in second language teaching and learning. Cambridge: Cambridge University Press.

Ho, S. T. K. (2009). Addressing Culture in EFL Classrooms: The Challenge of Shifting from a Traditional to an Intercultural Stance. Electronic Journal of Foreign Language Teaching, 6(1), 63-76.

Hofstede, G. (1991). Cultures and Organizations: Software of the Mind. New York: McGraw-Hill.

Hofstede, G., Hofstede, G. J., \& Minkov, M. (2010). Cultures and Organizations: Software of the Mind. Revised and expanded (3rd ed.). New York: McGraw-Hill.

Holliday, A. (1999). Small Cultures. Applied Linguistics, 20(2), 237-264. http://dx.doi.org/10.1093/applin/20.2.237

Jenkins, J. (2003). World Englishes: A resource book for students. London: Routledge.

Jenkins, J. (2011). Accommodating (to) ELF in the international university. Journal of Pragmatics, 43, 926-936. http://dx.doi.org/10.1016/j.pragma.2010.05.011

Kachru, Y., \& Nelson, C. L. (2006). World Englishes in Asian Contexts. Hong Kong: Hong Kong University Press.

Kramsch, C. (1993). Context and Culture in Language Teaching. Oxford: Oxford University Press.

Kramsch, C. (1995). The cultural component of language teaching. Language, culture and curriculum, 8(2), 83-92. http://dx.doi.org/10.1080/07908319509525192

Kramsch, C. (1998). Language and Culture. Oxford: Oxford University Press.

Kroeber, A., \& Kluckhohn, C. (1954). Culture: A Critical Review of Concepts and Definitions. New York: Random House.

Lai, H. Y. T. (2011). Taiwanese University Students' Perceptions of Learning English as an International Language. The International Journal of the Humanities, 9(1), 197-205.

Latulippe, L. (1999). Lessons learned from being a student again. TESOL Matters, 9(2), 13.

Lee, K. Y. (2009). Treating culture: What 11 high school EFL conversation textbooks in South Korea. English Teaching: Practice and Critique, 8, 76-96.

Liddicoat, A. J. (2002). Static and dynamic views of culture and intercultural language acquisition. Babel, 36(3), 4-11.

Liddicoat, A. J., Papademetre, L., Scarino, A., \& Kohler, M. (2003). Report on intercultural language learning. Canberra ACT: Commonwealth of Australia.

McKay, S. L. (2002). Teaching English as an International Language: Rethinking Goals and Approaches. Oxford: Oxford University Press.

McKay, S. L. (2003). Toward an appropriate EIL pedagogy: Re-examining common ELT assumptions. 
International Journal of Applied Linguistics, 13(1), 1-22. http://dx.doi.org/10.1111/1473-4192.00035

Mitchell, R., \& Myles, F. (2004). Second language learning theories (2nd ed.). London: Arnold.

Murphy, E. (1988). The cultural dimension in foreign language teaching: four models. Language, Culture and Curriculum, 1(2), 147-163. http://dx.doi.org/10.1080/07908318809525033

Nelson, C. L. (1995). Intelligibility and world Englishes in the classroom. World Englishes, 14(2), 273-279. http://dx.doi.org/10.1111/j.1467-971X.1995.tb00356.x

Nemni, M. (1992). Mefiez-vous du discours interculturel! Canadian Modern Language Review, 49(1), 10-36.

Pennycook, A. (1989). The concept of method, interested knowledge, and the politics of language teaching. TESOL Quarterly, 23(4), 589-614. http://dx.doi.org/10.2307/3587534

Peterson, B. (2004). Cultural intelligence: A guide to working with people from other cultures. Yarmouth, ME: Intercultural Press.

Rich, S. (2003). The importance of developing an intercultural approach in the foreign language classroom and some ways in which this can be achieved. Unpublished handout given at The $7^{\text {th }}$ Melta International Conference held in Kuala Lumpur from May $18^{\text {th }}-20^{\text {th }}, 2003$.

Risager, K. (1998). Language teaching and the process of European integration. In M. Byram, \& M. Fleming (Eds.), Language Learning in Intercultural Perspective (pp. 242-254). Cambridge: Cambridge University Press.

Robinson, G. L. N. (1988). Crosscultural Understanding. UK: Prentice Hall.

Saville-Troike, M. (1975). Teaching English as a second culture. In R. Crymes, \& W. Norris (Eds.). ON TESOL '74. Washington: TESOL.

Selfridge, R., \& Sokolik, S. (1975). A comprehensive view of organizational management. MSU Business Topics, 23(1), 46-61.

Smith, P. B., \& Bond, M. H. (1998). Social Psychology across Cultures. London: Prentice Hall Europe.

Stapleton, P. (2000). Culture's Role in TEFL: An Attitude Survey in Japan. Language, Culture, and Curriculum, 13(3), 291-305. http://dx.doi.org/10.1080/07908310008666605

Stempleski, S. (2000). Integrating Culture into English Teaching. Selected papers from the Proceedings of the Ninth International Symposium on English Teaching in the Republic of China. Taipei: The Crane Publishing Co.

Street, B. (1993). Culture is a verb: Anthropological aspects of language and cultural process. In D. Graddol, L. Thompson, \& M. Byram (Eds.), Language and Culture. Clevedon, Avon: Multilingual Matters and BAAL.

Williams, M., \& Burden, R. L. (1997). Psychology for Language Teachers. Cambridge: Cambridge University Press. http://dx.doi.org/10.1177/0261927X970163001

Yashima, T. (2000). Orientations and motivations in foreign language learning: A study of Japanese college students. JACET Bulletin, 31, 121-133.

Yashima, T. (2002). Willingness to communicate in a second language: The Japanese EFL context. Modern Language Journal, 86, 54-66. http://dx.doi.org/10.1111/1540-4781.00136

Yashima, T. (2009). International Posture and the Ideal L2 Self in the Japanese EFL Context. In Z. Dörnyei, \& E. Ushioda (Eds.), Motivation, Language Identity and the L2 Self (pp. 144-163). Bristol: Multilingual Matters.

Yashima, T., Zenuk-Nishide, L., \& Shimizu, K. (2004). The influence of attitudes and affect on willingness to communicate and second language communication. Language Learning, 54, 119-152. http://dx.doi.org/10.1111/j.1467-9922.2004.00250.x

\section{Copyrights}

Copyright for this article is retained by the author(s), with first publication rights granted to the journal.

This is an open-access article distributed under the terms and conditions of the Creative Commons Attribution license (http://creativecommons.org/licenses/by/3.0/). 